\title{
Persepsi Peternak Tentang Pemanfaatan Pakan Fermentasi Gedebog Pisang Untuk Sapi Potong Di Desa Tambaksari Kecamatan Purwodadi Kabupaten Pasuruan
}

\author{
Rezki Amalyadi*1, Ismulhadi*2, Wahyu Windari ${ }^{3}$ \\ 1,2,3 Program Studi Penyuluhan Peternakan dan Kesejahteraan Hewan, Polbangtan Malang \\ e-mail: rezkiamalyadi.stppmalang@gmail.com
}

\begin{abstract}
Abstrak
Penelitian bertujuan untuk mengetahui bagaimana persepsi peternak tentang pemanfaatan pakan fermentasi gedebog pisang untuk penggemukan sapi potong di Desa Tambaksari Kecamatan Purwodadi Kabupaten Pasuruan dan faktor-faktor yang mempengaruhi variabel pengamatan meliputi faktor internal dan faktor eksternal serta karakteristik individu meliputi umur, pendidikan dan pengalaman/lama beternak. Penelitian diawali dengan mengamati dan melibatkan diri pada komunitas peternak dalam konteks yang alami (natural setting), diskusi kelompok terfokus, dan wawancara mendalam serta pengisian angket kepada 60 peternak sapi potong yang tergabung dalam kelompoktani Ampelsari Makmur Jaya dan Ampelsari Makmur Jaya II. Hasil penelitian menunjukkan bahwa ada 35 orang menolak dan 25 orang menerima tentang inovasi pakan fermentasi gedebog pisang untuk penggemukan sapi potong. Dari hasil analisis diperoleh persamaan regresi linier berganda $\mathrm{Y}=6,486+0,128 \mathrm{X} 1+0,272 \mathrm{X} 2+(-0,006)$ $\mathrm{X} 3+(-0,337) \mathrm{X} 4+0,115 \mathrm{X} 5$ dengan $r$ sebesar 0,547 dan $r^{2}$ sebesar 0,299 dengan signiifikasi $\alpha$ 0,001 . Hal ini berarti faktor yang digunakan sangat berpengaruh terhadap persepsi dimana model dapat digunakan memperkirakan persepsi yang dipengaruhi oleh faktor internal, faktor eksternal, dan karakteristik individu (usia, pendidikan, dan pengalaman/lama beternak). Belum semua masyarakat berpersepsi positif terhadap pemanfaatan pakan fermentasi gedebog pisang untuk penggemukan sapi potong yang dipengaruhi oleh faktor internal, faktor eksternal dan karakteristik individu meliputi umur, pendidikan, dan pengalaman/lama beternak. Secara simultan terdapat pegaruh yang signifikan antara faktor internal, faktor eksternal, dan karakteristik individu (usia, pendidikan, dan pengalaman/lama beternak) terhadap persepsi. Sedangkan secara parsial terdapat pegaruh yang signifikan antara faktor eksternal terhadap persepsi.
\end{abstract}

Kata kunci: Persepsi, Faktor Internal, Faktor Eksternal, Karakteristik Individu (Umur, Pendidikan dan Pengalaman/Lama Beternak)

\begin{abstract}
The aim of the study was to determine the perceptions of farmers about the use of banana gedebog fermented feed for fattening beef cattle in Tambaksari Village, Purwodadi Subdistrict, Pasuruan Regency and the factors that influenced the observation variables including internal and external factors and individual characteristics including age, education and experience/length of farming. The research begins with observing and engaging with the farmer community in natural settings, focus group discussions, and in-depth interviews and filling out questionnaires to 60 beef cattle farmers who are members of the Ampelsari Makmur Jaya and Ampelsari Makmur Jaya II farmer groups. The results showed that there were 35 people refused and 25 people received about the innovation of gedebog banana fermented feed for fattening beef cattle. From the analysis results obtained by multiple linear regression equation $\mathrm{Y}=6,486+0,128 \mathrm{X} 1+0,272 \mathrm{X} 2+(-$ $0,006) \mathrm{X} 3+(-0,337) \mathrm{X} 4+0,115 \mathrm{X} 5$ with $\mathrm{r}$ of 0,547 and $\mathrm{r} 2$ of 0,299 with signification $\alpha 0,001$. This means that the factors used are very influential on perceptions where the model can be used to estimate perceptions that are influenced by internal factors, external factors, and individual characteristics (age, education, and experience/length of farming). Not all people have a positive perception of the use of banana gedebog fermented feed for fattening beef cattle which is influenced by internal factors, external factors and individual characteristics including age, education, and experience/length of livestock raising. Simultaneously there is a significant influence between internal factors, external factors, and individual characteristics (age, education,
\end{abstract}




\section{Jurnal Sains Peternakan}

Volume 7 No. 2, Desember 2019, pp:91-101

ISSN 2579-4450

and experience/length of livestock) to perception. While partially there is a significant influence between external factors on perception.

Keywords: Perception, Internal Factors, External Factors, Characteristics of Individuals (Age, Education and Experience / Length of Farming)

\section{Pendahuluan}

Tambaksari adalah Desa yang berada di Kecamatan Purwodadi Kabupaten Pasuruan Jawa Timur dengan luas lahan 773 Ha yang terdiri dari daerah dataran dengan ketinggian $670 \mathrm{mdpl}$, curah hujan $2.000 \mathrm{~mm} /$ tahun dan keadaan suhu rata-rata $26^{\circ} \mathrm{C}$ dengan jumlah penduduk 4.854 jiwa dimana 322 jiwa bekerja di sektor peternakan (Profil Desa Tambaksari, 2017: 1). Luas wilayah Desa Tambaksari berdasarkan atas tanah non sawah yaitu 290,88 Ha. Luas tersebut menunjukkan bahwa Desa Tambaksari memiliki lahan yang cukup luas untuk pakan ternak namun pada saat musim kemarau mengalami kekurangan pakan dikarenakan rumput yang dijadikan pakan utama ternak mati kekurangan air. Potensi ternak yang dibudidayakan di Desa Tambaksari yaitu sapi potong dengan populasi 258 ekor. Populasi tersebut tentu dibutuhkan pakan yang mendukung. Potensi pakan pada saat musim kemarau yang ada di Desa Tambaksari yaitu pisang dengan populasi tanaman $40 \mathrm{Ha}$ dimana masyarakat setelah panen pisang, batang pisang tersebut dibuang kesungai atau dibuang begitu saja tanpa dimanfaatkan. Padahal apabila ditangani dengan teknologi dapat dimanfaatkan sebagai pakan alternative bagi ternak dimusim kemarau.

Persaingan penggunaan lahan dewasa ini menyebabkan terbatasnya lahan untuk penanaman hijauan pakan ternak, sehingga ternak sebagai komoditi pemenuhan kebutuhan protein hewani sering mengalami kekurangan pakan terutama pada musim kemarau seperti yang dialami oleh peternak poktan Ampelsari Makmur Jaya dan Ampelsari Makmur Jaya II Desa Tambaksari Kecamatan Purwodadi Kabupaten Pasuruan. Berlimpahnya limbah pertanian seperti gedebog pisang diberikan tanpa pengolahan pakan terlebih dahulu.

Kelemahan batang pisang sebagai bahan pakan untuk ternak sapi jika diberikan secara langsung dalam bentuk alami adalah nilai palatabilitas yang rendah, adanya tannin suatu senyawa phenol yang akan mengganggu kecernaan bahan organik, khususnya protein dengan terbentuknya ikatan kompleks tannin-protein berlebihan yang sulit dicerna didalam sistem pencernaan sapi, dan kandungan serat kasar yang tinggi. Salah satu teknologi yang dapat digunakan untuk mengatasi kendala pemanfaatan batang pisang sebagai komponen ransum sapi adalah aplikasi teknologi bioproses dengan metode fermentasi anaerob (ensilage) dengan hasil akhir berbentuk silase/pakan 


\section{Jurnal Sains Peternakan}

Volume 7 No. 2, Desember 2019, pp:91-101

ISSN 2579-4450

fermentasi batang pisang untuk sapi potong.

Sebuah inovasi akan diterima dengan baik apabila masyarakat berpersepsi baik pula. Sehingga diperlukan pengukuran yang mendalam terhadap masyarakat tersebut serta faktor yang mempengaruhi sebagai dasar untuk penetapan langkah selanjutnya agar motivasi tentang pakan fermentasi gedebog pisang dapat diterima sepenuhnya oleh masyarakat.

\section{Materi dan Metode}

Penelitian ini dilakukan di Desa Tambaksari Kecamatan Purwodadi Kabupaten Pasuruan pada bulan November 2018 hingga Mei 2019 dengan sampel berjumlah 60 peternak yang tergabung dalam kelompoktani dengan teknik pengambilan sampel secara Total Sampling. Data yang diambil dalam penelitian ini adalah data primer dan sekunder. Data primer adalah data yang diperoleh langsung dari responden dengan cara wawancara, observasi dan penyebaran kuesioner. Data sekunder adalah data yang diperoleh dari instansi terkait yakni program dari Balai Penyuluhan Pertanian dan data dari Desa atau kelurahan.

Pengukuran persepsi peternak tentang pemanfaatan pakan fermentasi gedebog pisang untuk penggemukan sapi potong dan pengaruh faktor internal, faktor ekternal dan karakteristik individu (umur, pendidikan dan pengalaman/lama beternak) terhadap persepsi diukur menggunakan kuesioner. Variabel indenpenden meliputi faktor internal, faktor eksternal dan karakteristik individu (umur, pendidikan dan pengalaman/lama beternak). Sedangkan variabel dependen adalah persepsi peternak tentang pemanfaatan pakan fermentasi gedebog pisang untuk penggemukan sapi potong. Faktor internal terdiri dari latar belakang, kepribadian, sikap dan penerimaan diri. Sedangkan, faktor eksternal terdiri dari sesuatu yang baru, keakraban, ulangan, gerakan, kontras, ukuran, dan intensitas. Sedangkan karakteristik individu terdiri dari umur, pendidikan dan pengalaman/lama beternak. Pengukuran persepsi dan pengaruh faktor internal dan faktor eksternal terhadap persepsi dilakukan dengan menggunakan skala Likert dengan memberikan pernyataan tertutup terdiri dari pernyataan positif. Sebelum dibagikan kepada responden, dilakukan uji validitas dan reliabilitas kuesioner yang bertujuan agar kuesioner tersebut memiliki ketepatan dalam pengukuran dan dapat dipercaya. Untuk mengetahui pengaruh antara variabel terikat dan variabel bebas maka digunakan analisis regresi linier berganda. Penyimpulan persepsi menggunakan skor $\mathrm{T}$ dengan melihat deskriptif rata-rata dari hasil analisis data Software SPSS. Sedangkan pengaruh faktor internal dan faktor eksternal terhadap persepsi disimpulkan melalui hasil analisis data 


\section{Jurnal Sains Peternakan}

Volume 7 No. 2, Desember 2019, pp:91-101

ISSN 2579-4450

dengan menggunakan rumus regresi linier bergnada.

\section{Hasil Dan Pembahasan}

\section{Umur Penduduk}

Sumber Daya Manusia (SDM) di Desa Tambaksari sejumlah 4.854 orang yang dibagi menurut golongan usia dan jenis kelamin disajikan pada Tabel 1.

Tabel 1. Jumlah Penduduk Menurut Golongan Usia dan Jenis Kelamin

\begin{tabular}{|c|l|c|c|c|}
\hline \multirow{2}{*}{ No } & \multirow{2}{*}{ Golongan Umur } & \multicolumn{2}{|c|}{ Jenis Kelamin } & \multirow{2}{*}{$\begin{array}{c}\text { Jumlah } \\
\text { Penduduk }\end{array}$} \\
\cline { 3 - 4 } & & Laki-laki & Perempuan & 103 \\
\hline 1 & $0-12$ Bulan & 47 & 56 & 268 \\
\hline 2 & $13-4$ Tahun & 121 & 147 & 259 \\
\hline 3 & $5-6$ Tahun & 133 & 126 & 355 \\
\hline 4 & $7-12$ Tahun & 174 & 181 & 280 \\
\hline 5 & $13-15$ Tahun & 132 & 148 & 360 \\
\hline 6 & $16-18$ Tahun & 199 & 161 & 285 \\
\hline 7 & $19-25$ Tahun & 141 & 144 & 649 \\
\hline 8 & $26-35$ Tahun & 348 & 301 & 613 \\
\hline 9 & $36-45$ Tahun & 277 & 336 & 401 \\
\hline 10 & $46-50$ Tahun & 194 & 207 & 398 \\
\hline 11 & $51-60$ Tahun & 216 & 182 & 367 \\
\hline 12 & $61-75$ Tahun & 163 & 204 & 263 \\
\hline 13 & 75 Ke atas & 147 & 116 & 4.854 \\
\hline
\end{tabular}

Tabel 1 diketahui bahwa penduduk terbanyak berusia 26-35 Tahun yaitu 649 orang jadi dapat disimpulkan bahwa penduduk di Desa Tambaksari merupakan pada tahapan usia produktif. Menurut Karmila dalam Utami (2015:13), umur merupakan salah satu indikator yang menunjukkan kemampuan fisik seseorang. Dilihat dari jenis kelamin, penduduk di Desa Tambaksari ini mempunyai penduduk perempuan lebih banyak dari pada penduduk laki-laki. Jenis kelamin berkaitan dengan dikotomi peran yang harus dilakukan oleh perempuan dan laki-laki (Rokhmansyah, 2016: 9). Tingkat pendidikan penduduk di Desa Tambaksari disajikan pada Tabel 2.

Tabel 2 diketahui bahwa penduduk di Desa Tambaksari rata-rata menempuh pendidikan umum dengan jumlah terbanyak yaitu lulusan SD/Sederajat dengan total 2.161 kemudian diikuti dengan SLTP/Sederajat dengan total 900 orang. Pendidikan Menurut Murwanto dalam Utami (2015:13-14) bahwa tingkat pendidikan peternak merupakan indikator kualitas penduduk dan merupakan peubah kunci dalam pengembangan sumberdaya manusia. 


\section{Jurnal Sains Peternakan}

Volume 7 No. 2, Desember 2019, pp:91-101

ISSN 2579-4450

Tabel 2. Jumlah Pendidikan Berdasarkan Tingkat Pendidikan Penduduk

\begin{tabular}{|c|l|c|c|c|}
\hline No & \multicolumn{1}{|c|}{ Keterangan } & Laki-laki & Perempuan & Jumlah \\
\hline 1 & Pendidikan Umum & & & \\
\hline & a. SD/Sederajat & 1.563 & 1.598 & 2.161 \\
\hline & b. SLTP/Sederajat & 438 & 472 & 900 \\
\hline & c. SLTA/Sederajat & 314 & 324 & 638 \\
\hline & d. Akademi/Sederajat & 9 & 13 & 22 \\
\hline & e. Universitas/Perguruan Tinggi & 15 & 17 & 32 \\
\hline & Jumlah & 2.339 & 2.424 & 4.763 \\
\hline 2 & Pendidikan Khusus & & & \\
\hline & a. Pondok Pesantren & 18 & 24 & 42 \\
\hline & b. SLB & 1 & - & 1 \\
\hline & c. Kejar Paket A & 21 & 27 & 58 \\
\hline & Jumlah & 40 & 51 & 91 \\
\hline & Jumlah Seluruhnya & & & \\
\hline
\end{tabular}

Usaha peternakan faktor pendidikan diharapkan dapat membantu masyarakat dalam upaya peningkatan produksi dan produktifitas ternak yang dipelihara. Tingkat pendidikan yang memadai akan berdampak pada peningkatan kinerja dan kemampuan manajemen usaha peternakan yang dijalankan. Pengalaman/lama beternak disajikan pada Tabel 3.

Tabel 3 diketahui bahwa penduduk di Desa Tambaksari pengalaman/lama beternak bervariasi mulai dari 3 tahun hingga 13 tahun. Menurut Murwanto dalam Utami (2015:14-15) pengalaman beternak merupakan peubah yang sangat berperan dalam menentukan keberhasilan peternak dalam meningkatkan pengembangan usaha ternak dan sekaligus upaya peningkatan pendapatan peternak.

Tabel 3. Pengalaman/Lama Beternak

\begin{tabular}{|c|c|c|}
\hline No & Pengalaman/Lama Beternak (Tahun) & Jumlah (Orang) \\
\hline 1 & $3-5$ & 8 \\
\hline 2 & $6-10$ & 39 \\
\hline 3 & $11-13$ & 13 \\
\hline
\end{tabular}

\section{Potensi Desa Tambaksari}

Potensi peternakan di Desa Tambaksari Kecamatan Purwodadi Kabupaten Pasuruan menurut jenis ternak yang dibudidayakan beserta jumlah peternak disajikan pada Tabel 4.

Tabel 4. Potensi Peternakan

\begin{tabular}{|c|l|c|c|}
\hline No & Jenis Ternak & Jumlah Ternak (Ekor) & Jumlah KK Pemilik Ternak \\
\hline 1 & Sapi & 258 & 84 \\
\hline 2 & Kambing & 367 & 34 \\
\hline 3 & Ayam & 900 & 1 \\
\hline & Jumlah & 1.525 & 119 \\
\hline
\end{tabular}




\section{Jurnal Sains Peternakan}

Volume 7 No. 2, Desember 2019, pp:91-101

ISSN 2579-4450

Tabel 4 diketahui bahwa jenis ternak yang dipelihara penduduk di Desa Tambaksari terdiri dari sapi dengan jumlah 258 ekor, kambing dengan jumlah 367 ekor dan ayam dengan jumlah 900 ekor. Kepemilikan sapi di Desa Tambaksari rata-rata per keluarga sebanyak 2-3 ekor. Sapi pada umumnya dipelihara sebagai simpanan yang digunakan pada saat ada keperluan penting.

Sapi potong merupakan sapi yang dipelihara dengan tujuan utama sebagai penghasil daging. Sapi potong biasa disebut sebagai sapi tipe pedaging. Adapun ciri-ciri sapi pedaging adalah tubuh besar, berbentuk persegi empat atau balok, kualitas dagingnya maksimum, laju pertumbuhan cepat, cepat mencapai dewasa, efisiensi pakannya tinggi, dan mudah dipasarkan. Menurut Abidin (2006:98) sapi potong adalah jenis sapi khusus dipelihara untuk digemukkan karena karakteristiknya, seperti tingkat pertumbuhan cepat dan kualitas daging cukup baik.

Potensi sampingan dari hasil buah-buahan dapat dimanfaatkan sebagai pakan ternak. Data Hasil panen tanaman buah-buahan di Desa Tambaksari disajikan pada Tabel 5.

Tabel 5. Hasil Tanaman Buah-buahan

\begin{tabular}{|c|l|c|}
\hline No & \multicolumn{1}{|c|}{ Jenis Tanaman Sayuran } & Hasil Panen Ton/Ha \\
\hline 1 & Pisang & 4 \\
\hline 2 & Rambutan Jumlah & 0,25 \\
\hline & \multicolumn{2}{|c|}{ Jun } \\
\hline
\end{tabular}

Tabel 5 diketahui bahwa hasil tanaman buah-buahan di Desa Tambaksari terdapat

2 jenis yaitu pisang dan rambutan. Pisang yang dihasilkan di Desa Tambaksari menunjukkan angka 4 Ton/Ha. Total keseluruhan sebanyak 4,25 Ton/Ha. Tanaman pisang (Musa paradisiaca) merupakan sumber pakan yang penting, karena selain produktivitasnya tinggi juga menghasilkan produk limbah/sampingan yang beragam, sehingga relatif tersedia sepanjang tahun. Secara kumulatif, fraksi batang, daun atau anakan dapat menghasilkan bahan pakan (BK) sebesar 11,2 ton/ha, dengan pola ketersediaan sepanjang tahun. Luas areal tanam tanaman pisang diperkirakan mencapai 74.751 ha, sehingga potensi pakan asal tanaman pisang secara nasional mencapai sekitar 800.000 ton/tahun.

Beberapa daerah penting penghasil pisang antara lain yang terbesar adalah Jawa Barat dan Jawa Timur (>10.000 ha), Jawa Tengah, Lampung, Nusa Tenggara Barat, Sulawesi Selatan dan Banten (4.000-8.000 ha), serta Sumatera Utara, Sumatera Selatan, Bali, Nusa Tenggara Timur dan Kalimantan Selatan (1.300-2.600 ha) (Ginting, 2004:87). 


\section{Jurnal Sains Peternakan}

Volume 7 No. 2, Desember 2019, pp:91-101

ISSN 2579-4450

\section{Kandungan Nutrisi Pakan Fermentasi Gedebog Pisang}

Untuk menyusun sebuah ransum pakan ternak, peternak perlu mengetahui kandungan gizi pada berbagai jenis bahan baku pakan ternak yang akan dipakai. Hal ini sangat penting agar ransum pakan ternak yang disusun sesuai dengan kebutuhan hidup ternak baik energinya, proteinnya maupun vitamin dan mineralnya.

Tabel 6. Kandungan Nutrisi Pakan Fermentasi Gedebog Pisang.

\begin{tabular}{|l|c|}
\hline \multicolumn{2}{|c|}{ Kandungan Nutrisi } \\
\hline Bahan Kering & 5,25 \\
\hline Abu & 17,85 \\
\hline Lemak Kasar & 0,58 \\
\hline Protein Kasar & 7,08 \\
\hline Serat Kasar & 27,67 \\
\hline BETN & 46,57 \\
\hline
\end{tabular}

Berdasar data pada Tabel 6, diketahui bahan kering adalah 5,25\%. Kandungan abu adalah 17,85\%. Kandungan lemak kasar adalah 0,58\%. Kandungan Protein Kasar adalah 7,08\%. Kandungan serat kasar adalah 27,67\%. Kandungan BETN adalah 46,57\%.

Dibandingkan dengan batang pisang yang sudah dan belum terfermentasi kandungan Protein Kasarnya adalah 3,01\%. Kandungan Protein Kasar tersebut sangat rendah atau setara dengan Protein Kasar Jerami. Takaran pemberian yang anjurkan yaitu $20 \mathrm{~kg} / \mathrm{hari} /$ ekor dimana jumlah pemberian dapat berubah sesuai dengan palatabilitas sapi tersebut. Pakan fermentasi gedebog pisang juga dapat dicampurkan dengan rumput maupun konsentrat. Pada musim kemarau, pakan fermentasi gedebog pisang dapat dijadikan pakan pokok pengganti rumput untuk sapi.

Wina (2001:20) menjelaskan bahwa total produksi batang pisang dalam berat segar minimum mencapai 100 kali lipat dari produksi buah pisangnya sedangkan total produksi daun pisang dapat mencapai 30 kali lipat dari produksi buah pisang. Kandungan batang pisang dari Laboratorium Ilmu Nutrisi Makanan Ternak UNS memiliki kandungan nutrien bahan kering (BK) 87,7\%, abu 25,12\%, lemak kasar (LK) 14,23\%, serat kasar (SK) 29,40\%, protein kasar (PK) 3,01\% dan bahan ekstrak tanpa nitrogen (BETN) $28,24 \%$.

\section{Persepsi Peternak Tentang Pakan Fermentasi Gedebog Pisang}

Instrumen yang digunakan untuk pengukuran persepsi yaitu kuesioner dengan menggunakan skala likert dan menyimpulkan persepsi menggunakan skor $\mathrm{T}$ yang dianalisis menggunakan SPSS. Persepsi peternak dapat dilihat pada Tabel 7. 
Tabel 7. Persepsi Peternak Tentang Pakan Fermentasi Gedebog Pisang

\begin{tabular}{|l|c|c|c|}
\hline Kategori & Interval & N & $\%$ \\
\hline Menerima & T skor $>50$ & 35 & 58,33 \\
\hline MMenolak & T skor $<50$ & 25 & 41,67 \\
\hline \multicolumn{2}{|c|}{ Total } & 60 & 100 \\
\hline
\end{tabular}

Tabel 7, diketahui 35 (58,33\%) responden menerima tentang Pemanfaatan Pakan Fermentasi Gedebog Pisang dan $25(41,67 \%)$ responden menolak. Artinya, secara umum responden berpendapat bahwa pakan fermentasi gedebog pisang cocok untuk kebutuhan kelompok.

Menurut Robbin (2003:253), indikator-indikator persepsi ada dua macam yaitu penerimaan dan evaluasi. Penerimaan adalah indikator terjadinya persepsi dalam tahap fisiologis yaitu berfungsinya indera untuk menangkap rangsangan dari luar. Evaluasi adalah individu yang satu menilai suatu rangsangan sebagai suatu yang sulit dan membusankan. Individu yang lain menilai rangsangan yang sama tersebut sebagai suatu yang bagus dan menyenangkan. Setelah melalui tahap penerimaan lalu menuju tahap selanjutnya yakni evaluasi yang digunakan sebagai indikator pencapaian persepsi dari responden.

\section{Pengaruh Faktor Internal dan Eksternal Terhadap Persepsi Peternak Tentang Pakan Fermentasi Gedebog Pisang}

Pengukuran pengaruh faktor internal dan eksternal terhadap persepsi peternak dilakukan sebelum penyuluhan dengan tujuan untuk mengetahui faktor yang mempengaruhi persepsi dari materi yang akan di suluhkan. Instrumen yang digunakan yaitu kuesioner dengan menggunakan skala likert dan menganalisis dengan rumus regresi linier berganda dengan menggunakan software SPSS. Hasil Persamaan regresi berganda dapat dilihat sebagai berikut:

$\mathrm{Y}=6,486+0,128 \mathrm{X} 1+0,272 \mathrm{X} 2+(-0,006) \mathrm{X} 3+(-0,337) \mathrm{X} 4+0,115 \mathrm{X} 5$

Persamaan diatas digunakan sebagai dasar untuk memperkirakan tingkat persepsi yang dipengaruhi oleh faktor internal, faktor eksternal, usia, pendidikan, dan lama akan diuji apakah valid untuk digunakan. Hasil analisis SPSS diketahui bahwa korelasi secara parsial dimana korelasi parsial antara veriabel faktor internal (X1) dengan persepsi (Y) diperoleh nilai sebesar $r=0,384$. Nilai ini menunjukkan hubungan yang lemah positif antara X1 dan Y. Maksud lemah positif disini, terjadi hubungan yang searah antara X1 dan Y. Artinya, bila nilai X1 naik, maka persepsi akan naik signifikan. Korelasi parsial 
antara veriabel faktor eksternal (X2) dengan persepsi (Y) diperoleh nilai sebesar $r=$ 0,441. Nilai ini menunjukkan hubungan yang lemah positif antara X2 dan Y. Maksud lemah positif disini, terjadi hubungan yang searah antara X2 dan Y. Artinya, bila nilai X2 naik, maka persepsi akan naik. Korelasi parsial antara veriabel usia (X3) dengan persepsi (Y) diperoleh nilai sebesar $r=0,150$. Nilai ini menunjukkan hubungan yang lemah positif antara X3 dan Y. Maksud lemah positif disini, terjadi hubungan yang searah antara X3 dan Y. Artinya, bila nilai X3 naik, maka persepsi akan naik.

Korelasi parsial antara veriabel pendidikan (X4) dengan persepsi (Y) diperoleh nilai sebesar $r=-0,187$. Nilai ini menunjukkan hubungan yang lemah negatif antara X4 dan Y. Maksud lemah negatif disini, terjadi hubungan yang tidak searah antara X4 dan Y. Artinya, bila nilai X4 naik, maka persepsi akan turun. Korelasi parsial antara veriabel lama beternak (X5) dengan persepsi (Y) diperoleh nilai sebesar $r=0,174$. Nilai ini menunjukkan hubungan yang lemah positif antara X5 dan Y. Maksud lemah positif disini, terjadi hubungan yang searah antara X5 dan Y. Artinya, bila nilai X5 naik, maka persepsi akan naik. Korelasi (R) yang sangat simultan (Bersama-sama) antara variabel faktor interna (X1), faktor eksternal (X2), usia (X3), Pendidikan (X4), dan lama beternak (X5) terhadap persepsi (Y) diperoleh $r=0,547$. Kontribusi yang diberikan oleh lima variabel terhadap variabel $(\mathrm{Y})$.

$$
\begin{aligned}
\mathrm{KP} & =\left(r_{\mathrm{x} 1, \times 2, \mathrm{x} 3, \mathrm{x} 4, \mathrm{x} 5, \mathrm{Y}}\right)^{2} \times 100 \% \\
& =(0,547)^{2} \times 100 \% \\
& =29,92 \%
\end{aligned}
$$

Hipotesis berdasarkan uji $\mathrm{F}$ hanya digunakan untuk mengetahui apakah kedua variabel bebas secara bersama-sama (simultan) mempengaruhi satu variabel tak bebas. Kaidah pengujian, jika: $F_{\text {hitung }} \leq F_{\text {tabel }}$, maka Ho diterima. Jika: $F_{\text {hitung }}>F_{\text {tabel }}$, maka Ho

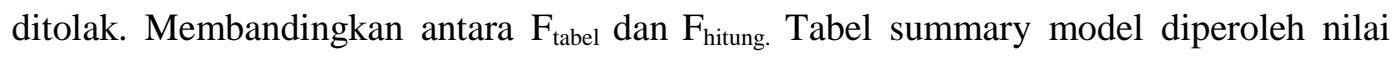
$F_{\text {hitung }}=4,6$. Nilai $F_{\text {tabel }}$ dapat dicari dengan menggunakan tabel $F$ dengan cara: $F_{\text {tabel }}=F_{\{(1-}$ $\alpha)(\mathrm{dk}$ pembilang $=\mathrm{m}),(\mathrm{dk}$ penyebut $=\mathrm{n}-\mathrm{m}-1)$. Dimana: $\mathrm{m}=5, \mathrm{n}=60, \alpha=0,05, \mathrm{dk}=60-5-1=54, \mathrm{~F}_{\text {tabel }}=$ $F_{\{(1-0,05)(54)}=2,7$. Ternyata $: F_{\text {hitung }}=4,6>F_{\text {tabel }}=2,7$ sehingga Ho ditolak. Keputusannya: terdapat pegaruh yang signifikan secara simultan (bersama-sama) antara faktor internal, faktor eksternal, dan karakteristik individu (usia, pendidikan, dan pengalaman/lama beternak) terhadap persepsi.

Berdasarkan teknik probabilitas, menentukan kriteria pengujian jika: Sig $\leq \alpha$, maka Ho ditolak dan jika: Sig $>\alpha$, maka Ho diterima. Tabel coefficients $(\alpha)$ diperoleh nilai sig $=0,016$. Nilai $\alpha$, karena uji dua sisi maka nilai $\alpha$-nya dibagi 2 , sehingga nilai $\alpha=$ 


\section{Jurnal Sains Peternakan}

Volume 7 No. 2, Desember 2019, pp:91-101

ISSN 2579-4450

$0,05 / 2=0,025$. Ternyata: $\operatorname{Sig}=0,016<\alpha=0,025$, maka Ho ditolak. Keputusannya adalah terdapat pegaruh yang signifikan secara parsial antara faktor eksternal terhadap persepsi.

Menurut Sobur (2016:389) faktor internal terdiri dari kebutuhan psikologis, latar belakang, kepribadian, sikap dan kepercayaan umum serta penerimaan diri, Sedangkan faktor eksternal terdiri dari intensitas, ukuran, kontras, gerakan, ulangan, keakraban, dan sesuatu yang baru. Karakteristik indovidu meliputi umur, pendidikan dan pengalaman/lama beternak. Kebutuhan Psikologis merupakan kebutuhan psikologis seseorang yang mempengaruhi persepsi. Latar Belakang merupakan pengaruh persepsi yang mengikuti dimensi tertentu dari setiap individu. Kepribadian merupakan pengaruh persepsi seseorang yang introvert kepada orang-orang yang sama maupun orang-orang yang serupa. Sikap dan Kepercayaan Umum merupakan kemungkinan-kemungkinan terjadi akibat dari sikap seseorang dan kepercayaan akan hal yang dipercaya. Penerimaan Diri merupakan seseorang yang lebih ikhlas menerima kenyataan diri akan lebih tepat menyerap sesuatu dari pada mereka yang kurang ikhlas menerima realitas dirinya. Intensitas adalah rangsangan yang lebih intensif mendapatkan lebih banyak tanggapan dari pada rangsangan yang kurang intensif. Ukuran adalah besar kecilnya suatu hal yang dilihat atau diamati. Kontras adalah biasanya hal-hal lain yang biasa dilihat akan cepat menarik perhatian. Gerakan adalah hal-hal yang bergerak lebih menarik perhatian dari pada hal-hal yang diam. Ulangan adalah hal yang berulang dan menarik perhatian dengan penggunaan yang hati-hati. Keakraban lebih dalam menarik perhatian dimana hal ini terutama apabila hal tertentu tidak diharapkan dalam rangka tertentu. Sesuatu yang baru lebih menarik dari keakraban dimana apabila orang tertentu terbiasa dengan yang sudah dikenal, maka sesuatu yang baru akan menaruh perhatian yang baru. Umur merupakan usia responden pada saat penelitian yang dinyatakan dalam tahun. Pendidikan merupakan suatu usaha mengembangkan suatu kepribadian dan kemampuan di dalam dan di luar sekolah dan berlangsung seumur hidup. Pengalaman/lama beternak merupakan faktor yang digunakan dalam mempersiapkan seseorang untuk mencari hal-hal yang mungkin serupa dengan pengalaman pribadinya.

\section{Kesimpulan}

Persepsi peternak tentang pemanfaatan pakan fermentasi gedebog pisang menunjukkan 35 orang menolak dan 25 orang menerima tentang inovasi pakan fermentasi gedebog pisang. Hasil dari analisis regresi linier berganda, faktor yang mempengaruhi persepsi secara parsial yaitu faktor eksternal yang terdiri dari sesuatu yang baru, keakraban, ulangan, gerakan, kontras, ukuran, dan intensitas. Sedangkan secara simultan 


\section{Jurnal Sains Peternakan}

Volume 7 No. 2, Desember 2019, pp:91-101

ISSN 2579-4450

menunjukkan bahwa semua faktor mempengaruhi persepsi meliputi faktor internal dan faktor eksternal serta karakteristik individu (umur, pendidikan, pengalaman/lama beternak. Berdasarkan hasil tersebut inovasi pemanfaatan pakan fermentasi gedebog pisang untuk penggemukan sapi potong dapat disebarluaskan melalui pendekatan individu dan kelompok.

\section{Daftar Rujukan}

Abidin. 2006. Pakan Sapi Potong. Yayasan Pengembangan Sinar Tani. Jakarta.

Ginting. 2004. Tanaman Pisang. ITB Bogor.

Robbins, S. P. 2003. Perilaku Organisasi. Konsep Kontroversi Aplikasi.

Rokhmansyah, Alfian. 2016. Pengantar Gender dan Feminisme. Yogyakarta: Penerbit Garudhawaca.

Sobur, A. 2016. Psikologi Umum. Pustaka Setia. Bandung.

Utami, L. S. 2015. Hubungan Karakteristik Peternak Dengan Skala Usaha Ternak Kerbau Di Desa Sumbang Kecamatan Curio Kabupaten Enrekang. http://repository.unhas.ac.id/bitstream/ handle/123456789/17004/UTAMI \%20LS\%20SKRIPSI.pdf?sequence=1 [Diakses tanggal 3 Mei 2019].

Wina, E. 2001. Tanaman Pisang Sebagai Pakan Ternak Ruminansia. Jurnal Wartazoa. 11 (1): 20-27. 